\title{
Hypochlorhydria and hypergastrinaemia in rheumatoid arthritis
}

\author{
T. J. DE WITTE, P. J. GEERDINK, C. B. LAMERS, \\ A. M. BOERBOOMS, AND J.K. VAN DER KORST ${ }^{1}$
}

From the Department of Medicine, University Hospital, Nijmegen, The Netherlands

SUMMARY In order to evaluate the incidence and aetiology of hypergastrinaemia 53 patients with seropositive rheumatoid arthritis were examined for gastric acid secretion, fasting serum gastrin. concentration, circulating parietal cell antibodies, and some parameters of the activity of inflam $\mathrm{m}_{\vec{b}}^{\vec{b}}$ mation of rheumatoid arthritis. The basal and maximum acid output was found to be subnormat in this group $(\mathrm{P}<0.01)$, and in 11 of these patients $(23 \%)$ the fasting serum gastrin levels were raised $(\mathrm{P}<0.05)$. This hypergastrinaemia correlated strongly with maximum acid output. Only io cases of achlorhydria or hypochlorhydria (maximum acid output less than $2 \mathrm{mmol} / \mathrm{l}$ ) was the serur gastrin level markedly raised. Two out of 5 patients with achlorhydria were found to have circulating parietal cell antibodies, and 1 had decreased absorption of vitamin $\mathbf{B}_{\mathbf{1 2}}$. No relationship was foun between serum gastrin and duration or activity of rheumatoid arthritis; nor was there a relationship between basal serum gastrin and the various antirheumatic drugs administered.

Rooney et al. (1973a, 1973b) have demonstrated a high incidence of hypergastrinaemia in patients with rheumatoid arthritis (RA). But the cause of this phenomenon was not established. The inflammatory activity, the duration of the rheumatoid arthritis, and the gastric acid secretion were found to be unrelated to serum gastrin levels, nor did the presence of rheumatoid factor in serum influence the serum gastrin levels (Rooney et al., 1976a, 1976b). We have therefore investigated the incidence and the possible causes of the increased fasting serum gastrin levels in patients with rheumatoid arthritis.

\section{Patients and methods}

Fifty-three patients were included in this study. 28 females and 25 males with a mean age of 55 years (range 17-74 years). All patients met the criteria of the American Rheumatism Association for the diagnosis of classical or definite rheumatoid arthritis (Ropes et al., 1959). The age of males and females was not statistically different. Mean duration of the RA was 9 years (range 1-35 years). All

Accepted for publication 10 April 1978

1 Present address: Amsterdam Centre for Rheumatic Diseases, Dr Jan van Breemenstraat, Amsterdam-W 1056 $\mathrm{AB}$, The Netherlands. Correspondence to Professor Dr J. K. van der Korst. patients had a positive haemagglutination reactio with sensitised sheep cells, according to the technique of Svartz-Schlossman, and none had undergone previous upper abdominal surgical operations.

Eight patients were not taking any antirheumatif medications; the others were receiving indomethacin; gold, or corticosteroids, or a combination of these drugs. The activity of joint inflammation was assessed by means of an articular index; tendernes warmth, and swelling of all joints were measureg by the same investigator.

A matched control group consisted of 28 persons 14 males and 14 females, with a mean age of 5 years (range 36-75 years) without any sign of rhes matoid arthritis. or upper abdominal complaints.

Fasting serum gastrin was measured by a radion immunoassay technique (Stadil and Rehfeld, 1973 Lamers and van Tongeren, 1977). The gastrim antiserum was raised in a rabbit against synthetif human gastrin I containing residues 2 through (SHG 2-17, Imperial Chemical Industries Ltd conjugated to bovine albumin. Gastrin components I, II (gastrin-34), III (gastrin-17), and IV (gastrin 13) could be demonstrated by using this antibod $\overline{0}$ The antibody reacted with sulphated and nor sulphated forms of gastrins I, II, and III with almogit equimolar potency (Rehfeld et al., 1975).

Gastric contents were collected according to the 
method of Hector (1968); the correct position of the orogastric tube in the stomach was checked by the water recovery test (Hassan, and Hobsley 1970). Pentagastrin in a dose of $6 \mu \mathrm{g}$ per $\mathrm{kg}$ body weight was used for maximum stimulation of acid secretion. The gastric acid concentration was determined by titration of gastric juice with $0 \cdot 1 \mathrm{~N} \mathrm{NaOH}$ up to $\mathrm{pH}$ of $7 \cdot 0$. The basal acid output (BAO) during 1 hour, the maximum acid concentration (MAC) and the maximum acid output (MAO) during 1 hour were calculated.

The presence of circulating antibodies to parietal cells and intrinsic factor was measured according to the method of Taylor et al. (1962). Other immunological investigations performed on all patients were the sheep cell agglutination test, latex fixation reaction, antinuclear antibody test, and antiperinuclear antibody test (Nienhuis and Mandema, 1963). The following parameters of inflammatory activity were recorded: erythrocyte sedimentation rate (ESR), haemoglobin, and protein electrophoresis.

Statistical analyses were carried out by the Wilcoxon test for unpaired data. Regression analyses were done by the method of least squares.

\section{Results}

In 11 out of the 53 patients investigated fasting serum gastrin levels were raised, while none were raised in the 28 matched controls. The serum gastrin level of the whole group, $158 \mathrm{pg} / \mathrm{ml}$ (range 44-790 $\mathrm{pg} / \mathrm{ml})$, was significantly $(\mathrm{P}<0 \cdot 05)$ higher than in the matched control group, $67 \mathrm{pg} / \mathrm{ml}$ (range 43-97 $\mathrm{pg} / \mathrm{ml}$ ). As shown in Table 1 , the basal gastric acid output, maximum acid output, and maximum acid concentration were significantly $(P<0.01)$ lower than in a group of 20 healthy persons. This population was subdivided into 5 different groups in accordance with the MAO, namely, total achlorhydria (group A); severe hypochlorhydria, MAO 0-2 $\mathrm{mmol} / \mathrm{h}$ (group B); mild hypochlorhydria, MAO 2-6 mmol/h (group C); moderate hypochlorhydria,

Table 1 Gastric acid secretion in patients with rheumatoid arthritis and in healthy controls

\begin{tabular}{llllll}
\hline & $\begin{array}{l}\text { Patients } \\
(n=53)\end{array}$ & \multicolumn{4}{c}{$\begin{array}{l}\text { Controls } \\
(n=20)\end{array}$} \\
\cline { 2 - 6 } & Mean & Range & Mean & Range & $P$ \\
\hline $\begin{array}{c}\text { Basal acid output } \\
\text { (mmol/h) } \\
\text { Maximum acid } \\
\begin{array}{c}\text { output } \\
\text { (mmol/h) }\end{array}\end{array}$ & 1.2 & $0-11.4$ & 2.3 & $0-9.7$ & $<0.01$ \\
$\begin{array}{c}\text { Maximum acid } \\
\text { concentration } \\
\text { (mmol/1) }\end{array}$ & 83 & $0-29.4$ & 23.3 & $6.5-50.3$ & $<0.01$ \\
\hline
\end{tabular}

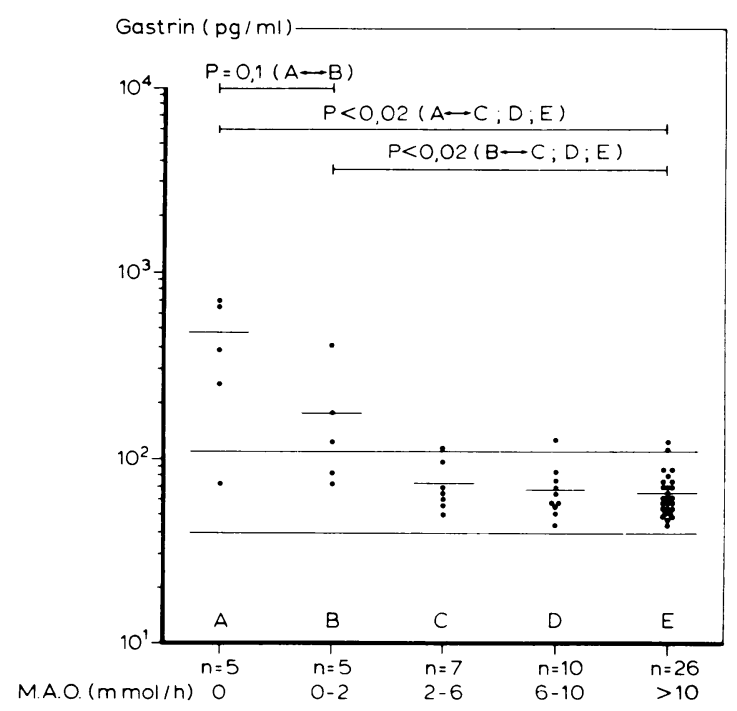

Fig. 1 Correlation between fasting serum gastrin concentrations and maximum acid output in patients with seropositive $R A$. The mean for each group is shown as a solid line. Gastrin has been plotted on a logarithmic scale.

MAO 6-10 mmol/h (group D); and MAO more than $10 \mathrm{mmol} / \mathrm{h}$ (group E) (Fig. 1).

Markedly increased serum gastrin concentrations were found almost exclusively in patients with achlorhydria (group A) or severe hypochlorhydria (group B). These patients had significantly $(\mathrm{P}<0.02)$ higher serum gastrin levels than patients in groups C, D, and E. Group A showed a weak tendency for higher gastrin levels than group $B(P=0 \cdot 1)$. Two out of 5 patients with achlorhydria had parietal cell antibodies, and none had demonstrable antibodies against intrinsic factor. Only 1 patient showed an impaired absorption of vitamin $\mathrm{B}_{12}(2 \cdot 3 \%$ excretion of labelled vitamin $B_{12}$ in 48-hours urine; normal more than $15 \%$ in 48 -hours), but this patient had no evidence of pernicious anaemia. None of the other patients had demonstrable circulating parietal cell or intrinsic factor antibodies.

In the RA patients with MAO more than 2 $\mathrm{mmol} / \mathrm{h}$ there was no significant correlation between BAO and serum gastrin $(r=0 \cdot 22)$ and between MAO and serum gastrin $(r=0 \cdot 03)$. Furthermore, we found no correlation between the serum gastrin level and the age of the patients, duration of the rheumatoid arthritis, articular joint index, subcutaneous nodules, ESR, haemoglobin, antiperinuclear antibodies, and antinuclear antibodies. As shown in Fig. 2, no relation was found between serum gastrin levels and the various antirheumatic drugs used. 


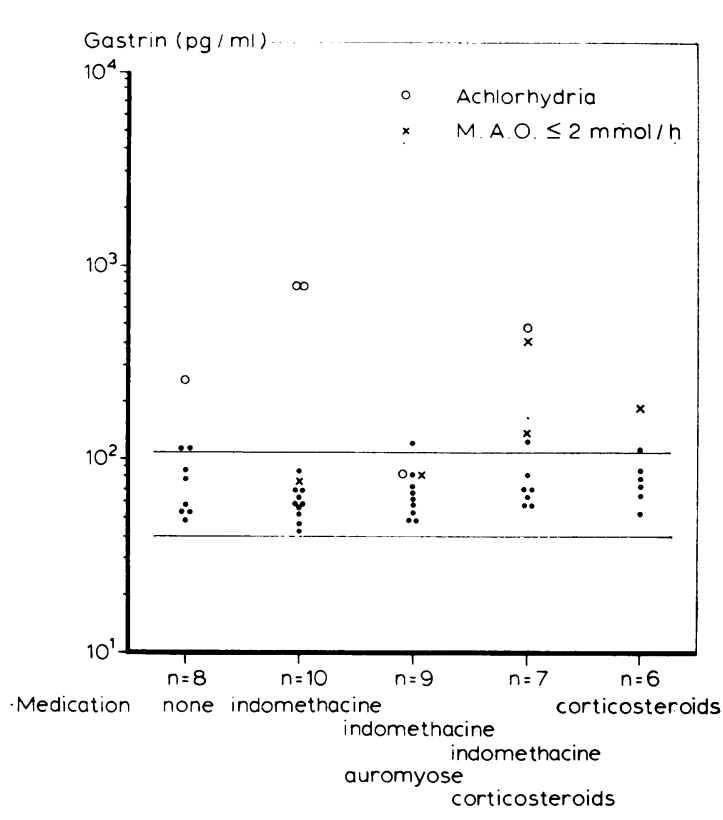

Fig. 2 Fasting serum gastrin levels in patients receiving various antirheumatic drugs. Patients with achlorhydria are represented by open circles and those with severe hypochlorhydria (MAO $2 \mathrm{mmol} / \mathrm{h})$ by crosses. The normal range, expressed as mean $\pm 2 \mathrm{SD}$, is indicated.

\section{Discussion}

In a group of 53 patients with seropositive, definite or classical, rheumatoid arthritis a high frequency of hypergastrinaemia ( $23 \%$ ) has been established. This is in accordance with the findings of Rooney et al. (1973a, 1973b, 1976a, 1976b). Whereas these authors found normal gastric acid output in almost all of their 16 RA patients with hypergastrinaemia, according to our data this hypergastrinaemia in rheumatoid patients appears to be based on an absence or severe reduction of gastric acid secretion. There is no ready explanation for the discrepancy between the findings of Rooney et al. (1976b) and our own results, although in contrast to our study Rooney and coworkers did not include rheumatoid patients with normal serum gastrin levels in their study. Nor did they show whether there is any relationship between serum gastrin levels and gastric acid secretion in their hypergastrinaemic patients. Generally, serum gastrin levels are increased in patients with reduced gastric production (Walsh and Grossman, 1975). Moreover, in patients with hypochlorhydria there is an inverse correlation between stimulated acid secretion rate and fasting serum gastric concentration (Trudeau and $M$ Guigan, 1971; Gedda-Dahl, 1974). The increase $\overrightarrow{\text { क }}$ serum gastrin levels in these conditions are caused b $\vec{b}$ the lack of inhibition of antral gastrin release due tळ the absence of gastric acid (Yalow and Berson $\overline{\bar{p}}$. 1970; Fahrenkrug et al., 1976).

In addition to the hypergastrinaemia a very high incidence of decreased gastric acid secretion was seen in our patients; only $50 \%$ of the patients had $\vec{D}$ normal maximum acid output (that is, higher than $10 \mathrm{mmol} / \mathrm{h}$ ). The mean fasting serum gastrin levet was found to be increased only if the MAO waP lower than $2 \mathrm{mmol} / \mathrm{h}$. In a study of nonrheumatoi patients the mean gastrin level was found to be raised if the MAO was less than $10 \mathrm{mmol} / \mathrm{h}$, but only if MAO was lower than $2 \mathrm{mmol} / \mathrm{h}$ did the mearf fasting gastrin reach very high levels (Gedda-Dahl? 1974). As in other studies (Trudeau and McGuigan1971; Gedda-Dahl, 1974) some of our patients witla a MAO $<2 \mathrm{mmol} / \mathrm{h}$ had a normal fasting serunt level of gastrin. Stockbrügger et al. (1977) found than in normogastrinaemic patients with achlorhydria the number of antral G-cells had not increasedco probably as a result of coexisting antral gastritis. ç

In general it has been assumed that achlorhydria and severe hypochlorhydria are an expression of chronic atrophic gastritis (Bock et al., 1963; Stock brügger et al., 1977). Louyot et al., (1974) have established histological evidence of gastritis in $40 \%$ and hypochlorhydria or achlorhydria in $60 \%$ of group of 50 rheumatoid patients. We abstained fron? taking gastric biopsies in our patients because it was considered unjustifiable to perform this procedure for experimental reasons only. Moreover, a smait sample biopsy cannot conclusively exclude the presence of chronic atrophic gastritis. Atrophie gastritis, as demonstrated by others, resulting in low gastric acid secretion can be accounted for̂ either by the rheumatoid arthritis itself or by the long-term administration of anti-inflammatory? drugs.

In the present study no relation was found bet을 ween gastric acid secretion and the antirheumatio drugs given. Although in both studies no relation was found between the hyposecretion of gastriê acid and the duration or activity of the rheumatie process, a possible role of the rheumatoid arthritis itself in the development of the hypochlorhydries cannot be excluded. Moreover, the increase of serun gastrin levels in untreated adjuvant arthritis in the rat also indicates a causative role of the inflammatoryo process itself (Rooney et al., 1973c).

In conclusion, the high incidence of hypergas trinaemia in patients with RA is, in our opiniong due to achlorhydria or severe hypochlorhydria, an probably is the result of chronic atrophic gastritis 


\section{References}

Bock, O. A., Richards, W. C., and Witts, L. J. (1963). The relationship between acid secretion after augmented histamine stimulation and the histology of the gastric mucosa. Gut, 4, 112-114.

Fahrenkrug, J., Schaffalitzky, O. B., Hornum, I., and Rehfeld, J. F., (1976). The mechanism of hypergastrinaemia in achlorhydria. Gastroenterology, 71, 33-37.

Gedda-Dahl, D. (1974). Fasting serum gastrin levels in humans with low pentagastrin-stimulated gastric acid secretion. Scandinavian Journal of Gastroenterology, 9, 597-599.

Hassan, M. A., and Hobsley, M. (1970). Positioning of subject and nasogastric tube during a gastric secretion study. British Medical Journal, 1, 458-460.

Hector, R. M. (1968). Improved technique of gastric aspiration. Lancet, 1, 15-16.

Lamers, C. B. H., and van Tongeren J. H. M. (1977). Comparative study of the value of the calcium, secretin and meal stimulated increase in serum gastrin to the diagnosis of the Zollinger-Ellison syndrome. Gut, 18, 128-134.

Louyot, P., Tamisier, J. N., Jeanpierre, J., Pourel, J., Zannetti, A., and Bertrand, P. (1974). Le compartement gastrique au cours des rhumatismes inflammatoires sous incidence médicamenteuse. Revue du Rhumatisme, 41, 725-732.

Nienhuis, R., and Mandema, E. (1963). A new serum factor in patients with rheumatoid arthritis: the antiperinuclear factor. Annals of the Rheumatic Diseases, 21, 302-305.

Rahfeld, J. F., Stadil, F., and Malmström, J. (1975). Gastrin heterogeneity in serum and tissue. In Gastro-intestinal Hormones, p. 34. Edited by J. C. Thompson. University of Texas Press: Austin and London.

Rooney, P. J., and Dick, W. C. (1973a). Hypergastrinaemia in rheumatoid arthritis. British Medical Journal, 4, 298.

Rooney, P. J., Vince, J., Kennedy, A. C., Webb, J., Lee, P., Dick, W. C., Buchanan, K. D., Hayes, J. R., Ardill, J., and Connor, F. (1973b). Hypergastrinaemia in rheumatoid arthritis: disease or iatrogenesis? British Medical Journal, 2, 752-753.
Rooney, P. J., Dick, W. C., Imrie, R. C., and Buchanan, K. D. (1973c). An animal model for the study of the relationship between immunoreactive gastrin and inflammatory arthritis. Nature, 246, 497-498.

Rooney, P. J., Grennan, D. M., Sturrock, R. D., Brooks, P. M., and Dick, W. C. (1976a). Serum immunoreactive gastrin: specificity for rheumatoid arthritis, bimodality of distribution and failure of effect of anti-inflammatory drugs. Annals of the Rheumatic Diseases, 35, 40-45.

Rooney, P. J., Kennedy, A. C., Gray, G. H., Sturrock, R. D., Buchanan, K. D., and Dick, W. C. (1976b). Immunoreactive gastrin in rheumatoid arthritis; further observations on its identity, clinical specificity and relationship to gastric function. Annals of the Rheumatic Diseases, 35, 246-250.

Ropes, M., Bennett, J., Cobb, S., Jacox, R., and Jessar, R. A. (1959). 1958 Revision of diagnostic criteria for rheumatoid arthritis. Arthritis and Rheumatism, 2, 16-20.

Stadil, F., and Rehfeld, J. F. (1973). Determination of gastrin in serum: an evaluation of the reliability of a radioimmunoassay. Scandinavian Journal of Gastroenterology, 8, 101-112.

Stockbrügger, R., Larsson, L. I., and Lundquist, G. (1977). Antral gastrin cells and serum gastrin in achlorhydria. Scandinavian Journal of Gastroenterology, 12, 209-213.

Taylor, K. B., Roitt, I. M., Donlach, D., Couchman, A., and Shapland, C. (1962). Autoimmune phenomena in pernicious anaemia; gastric antibodies. British Medical Journal, 2, 1347-1352.

Trudeau, W. L., and McGuigan, J. E. (1971). Relations between serum gastrin levels and rates of gastric hydrochloric acid secretion. New England Journal of Medicine, 284, 408-412.

Walsh, J. H., and Grossman, M. I. (1975). Gastrin. New England Journal of Medicine, 292, 1324-1334 and 13771383.

Yalow, R. S., and Berson, S. A. (1970). Radio-immunoassay of gastrin. Gastroenterology, 58, 1-14. 